\title{
ADDITIVE MANUFACTURING: THE FUTURE OF MANUFACTURING
}

\author{
DODAJALNA (3D) TEHNOLOGIJA: PRIHODNOST PROIZVAJANJA
}

\author{
Sheriff Adefemi Adekanye ${ }^{1}$, Rasheedat Modupe Mahamood ${ }^{1,2}$, \\ Esther Titilayo Akinlabi ${ }^{2}$, Moses Gbadebo Owolabi ${ }^{3}$ \\ ${ }^{1}$ University of Ilorin, Department of Mechanical Engineering, Nigeria \\ ${ }^{2}$ University of Johannesburg, Department of Mechanical Engineering Science, South Africa \\ ${ }^{3}$ Howard University, Department of Mechanical Engineering, Washington, USA \\ adekanyefm@gmail.com \\ Prejem rokopisa - received: 2016-08-26; sprejem za objavo - accepted for publication: 2017-03-16
}

doi:10.17222/mit.2016.261

\begin{abstract}
Additive manufacturing is an advanced manufacturing method used to fabricate prototypes, tooling as well as functional products. Additive manufacturing helps us produce complex parts as single-unit objects, which was not possible with the traditional manufacturing methods. There are different types of additive-manufacturing technologies, including selective laser melting, laser-metal-deposition process, fused deposition modeling and electron-beam melting. All these additive-manufacturing technologies produce three-dimensional (3D) objects by adding materials layer after layer. A 3D object is built directly from a 3D computer-aided-design (CAD) model of the object. Additive manufacturing is a very promising method for the aerospace industry, in particular because of its ability to reduce the buy-to-fly ratio. This technology is the technology of the future because it is going to change the way products are designed and manufactured. In this research, various additive-manufacturing technologies are described in detail and some of the research works in this field are also presented. The future research directions are also highlighted.

Keywords: additive manufacturing, fused deposition modelling, laser metal deposition, selective laser melting, selective laser
\end{abstract} sintering

Dodajalni proizvodni proces je napredna tehnologija, ki se uporablja za izdelavo prototipov, orodij in funkcionalnih izdelkov. Z naprednim proizvodnim procesom lahko izdelamo izdelke ali dele kompliciranih oblik, ki jih ni možno izdelati s tradicionalnim metodami proizvodnje. Obstajajo različne vrste naprednih dodajalnih tehnologij, kot so na primer: selektivno lasersko nataljevanje, proces laserskega nanašanja (depozicije) kovin, modeliranje $\mathrm{z}$ nanašanjem staljenih kapljic in taljenje $\mathrm{z}$ elektronskim curkom. Vse te napredne dodajalne tehnologije omogočajo izdelavo tridimenzionalnih (3D) izdelkov z dodajanjem materialov plast za plastjo. Tridimenzionalni produkt je izgrajen neposredno s pomočjo 3D-računalniško podprtega modeliranja (angl. CAD). Napredna dodajalna proizvodnja je zelo obetavna proizvodna metoda, predvsem v letalski in vesoljski industriji, še posebej zaradi sposobnosti zmanjševanja stroškov izdelave (zmanjšanje razmerja med maso materiala, potrebnega za izdelavo določenega izdelka in njegovo dejansko maso).

Ključne besede: dodajalna proizvodnja, modeliranje z nanašanjem staljenih materialov, laserska depozicija kovin, selektivno lasersko nataljevanje, selektivno lasersko sintranje

\section{INTRODUCTION}

The additive-manufacturing process is an advanced manufacturing process that produces three-dimensional (3D) objects directly from the 3D computer-aided-design (CAD) digital information of the parts by adding materials layer by layer. ${ }^{1-3}$ This is different from the traditional manufacturing that involves material removal or an energy-intensive process such as machining, casting and forging. With additive manufacturing, a complex-shaped product can be produced as a single object, which was not possible in the past.

For the traditional manufacturing process, complex parts have to be designed based on the ease of manufacturing the parts. Complex parts are usually broken down into smaller parts because of the ease of manufacturing those parts and the pieces are assembled at the later stage through various joining processes. This practice does not only involve labor-intensive processes but also results in wastage of materials, in addition to the materials re- moved during shaping and cutting operations; the excess materials added for joining also contribute to material wastage. The net weight of a product is also very large because of the excess materials used during the assembly. The additive-manufacturing technology, on the other hand, can make a product directly from the 3D CAD model of the product by just adding materials layer by layer. Irrespective of the complexity, any part that can be drawn using any computer-aided-design software can be made and as a single-unit object. Additive-manufacturing technologies are classified into seven main groups, namely: powder-bed fusion, directed energy deposition, sheet lamination, material extrusion, binder jetting, material jetting and vat photopolymerization. ${ }^{1} \mathrm{~A}$ designer does not need to worry about the manufacturability of a product; he/she is only concerned with the functionality of the part being designed.

At the inception, the additive manufacturing process was used to make prototypes because of the limitation in 


\section{S. A. ADEKANYE et al.: ADDITIVE MANUFACTURING: THE FUTURE OF MANUFACTURING}

the choice of the materials that could be used on an additive-manufacturing machine at that time. ${ }^{2-4}$ There are a number of industries benefiting from this revolutionary manufacturing technology, ${ }_{5}^{5}$ such as the aerospace, automobile and biomedical industries. ${ }^{6-9}$ In this study, some of these additive-manufacturing technologies are reviewed with the aim of throwing light on these technologies and describing their systems of operation as well as their advantages, limitations and areas of applications.

The rest of the paper is organized as follows: section 2 of the paper presents the powder-bed-based process. The extrusion-based process and sheet-lamination process are presented in sections 3 and 4, respectively. Directed-energy-deposition process is presented in section 5. Material development in additive manufacturing is presented in section 6, while conclusions are presented in section 7 .

\section{POWDER-BED-BASED PROCESS}

This class of additive manufacturing technology uses the energy from an electron beam or laser beam to fuse or melt powder materials for the manufacturing of parts. ${ }^{10,11}$ The additive-manufacturing technologies in this class include direct metal laser sintering (DMLS), electron-beam melting (EBM), selective heat sintering (SHS), selective laser melting (SLM) and selective laser sintering (SLS). Each of these technologies is described in this section.

\subsection{Direct metal laser sintering (DMLS)}

A schematic diagram of direct laser sintering is shown in Figure 1 below. This process manufactures parts by compacting a metal powdered material with a power source such as laser, without melting but by binding the material together to create a solid structure defined by the 3D CAD model of the part. ${ }^{12}$ The working principle of this technology makes it capable of designing and producing complex geometry of both internal and external intricacies. In this process, to avoid the collision of the recoater blade when moving, the building and dispenser platforms are lowered by the layer thickness. The powder metal needed to create a layer of the material is supplied by the dispenser platform after it

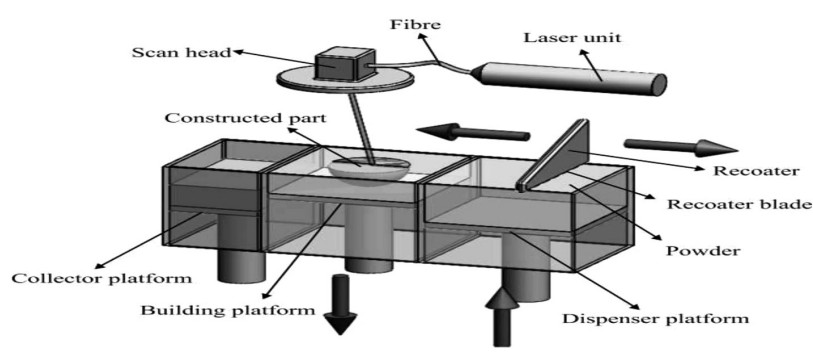

Figure 1: Schematic diagram of the direct metal laser sintering system $^{14}$ has been ensured that the recoater stands in the right position. The spreading of the metal powder from the dispenser to the building platform is done by the recoater, moving from the right to the left position, and the excess metal powder falls into the excess-powder collector. The scan head moves the laser beam through the two-dimensional (2D) cross-section, which is switched on and off during the exposure of designated areas. The powdered metals are generated, cured and sintered by the solidified areas through the absorption of energy. ${ }^{13}$ This process continues to create layer after layer until the part is completed. Using this process, parts have been successfully made from the materials such as aluminium alloys - AlSil0Mg, stainless steel, titanium alloys and cobalt chrome superalloy. ${ }^{13}$ Some of the advantages of this additive-manufacturing process are highlighted below. ${ }^{12,13}$

High speed: parts are produced easily within hours since special tools are not required.

Complex geometry: this technology allows designs of both internal and external features.

High quality: it creates parts with high accuracy and detailed resolution.

It provides parts with better mechanical strength.

In spite of all these advantages, some of the limiting factors are as follows: the process is expensive and power intensive, the surface needs to be polished and the metal support structure removed, and the thermal post-processing is time consuming. ${ }^{14,15}$

\subsection{Electron-beam melting}

Figure 2 shows a schematic presentation of an electron-beam process. Parts are developed by adding material layer by layer, following the path described by the $3 \mathrm{D}$ CAD data program. ${ }^{16}$ Electron beam is generated within an electron-beam gun; the tungsten filament is heated to an extremely high temperature so that it releases electrons; the electrons are accelerated with an electric field and then focused with electromagnetic coils. ${ }^{17,18}$ The electron beam melts each layer of the

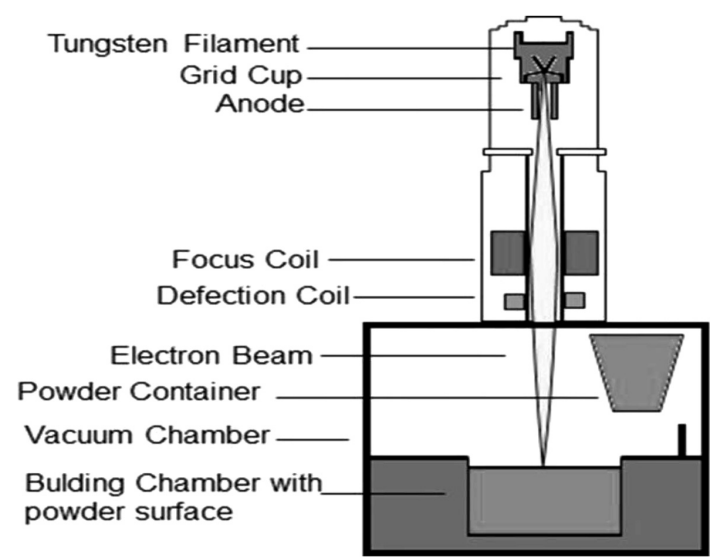

Figure 2: Schematic drawing of an electron-beam additive-manufacturing machine ${ }^{18}$ 
metal powder to the desired geometry in a vacuum; the process in the vacuum eliminates impurities and yields high-strength properties of the material under processing. ${ }^{16}$ The materials used for electron-beam melting are mainly steel and titanium alloy. The following advantages are characteristic of this technology: ${ }^{17}$

- an increased efficiency of the raw-material use,

- the vacuum eliminates impurities and provides a good thermal environment for a freeform fabrication,

- it significantly reduces the amount of finishing operations,

- freedom in design - design for functionality,

- processing of high-melting-point and highly reactive materials,

- decreased lead times for design and fabrication,

- a high degree of component customization.

Some of the disadvantages of the electron-beam technology include the following: ${ }^{19}$

- It requires a vacuum, another system to the machine, which must be maintained, leading to a high cost.

- It produces X-rays while in operation, which is hazardous.

\subsection{Selective laser sintering}

Selective laser sintering is also a powder-bed-based technology that involves the spreading of powder and the subsequent compaction. A schematic diagram of the selective laser sintering is shown in Figure 3. The set-up is made up of a laser, an automatic powder-layering apparatus, and a computer system for process control. ${ }^{20}$

Selective laser sintering uses a substrate for the part fabrication, which is fixed onto the building platform and leveled. The sealed building chamber containing oxygen has a reduced amount of oxygen due to the protective inert gas such as argon, which is fed into the chamber. A thin layer of a loose powder is deposited on the substrate by the layering mechanism. The laser beam scans the powder-bed surface through the CAD program forming layers of the material to be produced. The powder spreading and laser-treatment process are repeated and

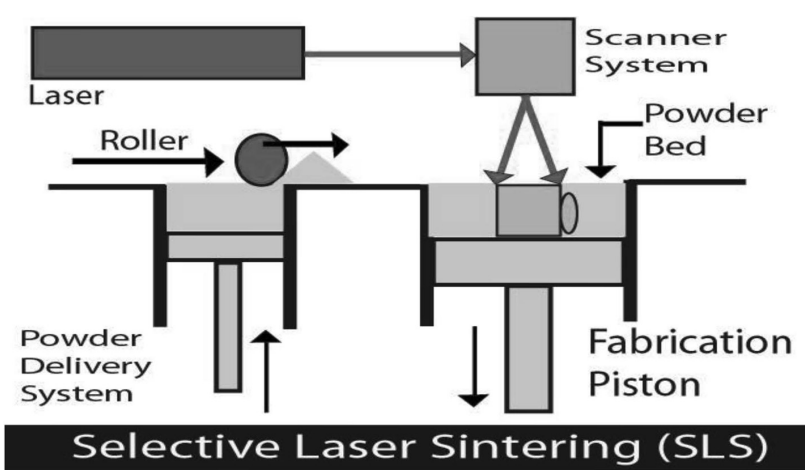

Figure 3: Schematic presentation of a selective-laser-sintering apparatus $^{21}$ the parts are built layer by layer until completion. ${ }^{21-23}$ This technology allows a variety of materials, the most common are: wax, paraffin, polymer-metal powders or various types of steel alloys, polymers, nylon and carbonates. ${ }^{24}$ The advantages of using selective laser sintering include:

- parts can be created out of a wide selection of materials,

- complex geometry is made easy as long as the non-sintered powder can be removed easily,

- when printing overhanging, unsupported structures, supports are not needed because the unused powder provides the necessary support.

Disadvantages of selective laser sintering are:

- the equipment is very expensive,

- the most common problem of this technology is that the fabricated parts are porous and the surface could be rough, depending on the materials used,

- thermal distortion occurs on polymer parts and can cause shrinking and warping of the fabricated parts.

\subsection{Selective heat sintering}

Figure 4 shows a schematic presentation of the selective-heat-sintering process, which operates by selectively fusing a thin layer of polymer powder through a thermal print-head assembly. This assembly operates bi-directionally and incorporates thermal print heads at point $\mathrm{A}$ as shown in the diagram. The part labelled as $\mathrm{B}$ is the powder-deposition mechanism, $\mathrm{C}$ is the layer heater, $\mathrm{D}$ is the chamber for the material built up in an internal build volume, $\mathrm{E}$ is the floor that is a vertically movable building platform; at F, fresh powder is supplied via scoops to the powder-deposition mechanism from the powder containers. ${ }^{25}$ The heated building platform builds up the parts, using the layer technology, with the roller spreading across the plastic powders in layers. The thermal print head of the apparatus forms a part in its full cross-section with the already laid powder. The heat at the building platform sinters the top layer of the powder; once completed, the process is repeated until a complete $3 \mathrm{D}$ object is produced. The complex geometries pro-

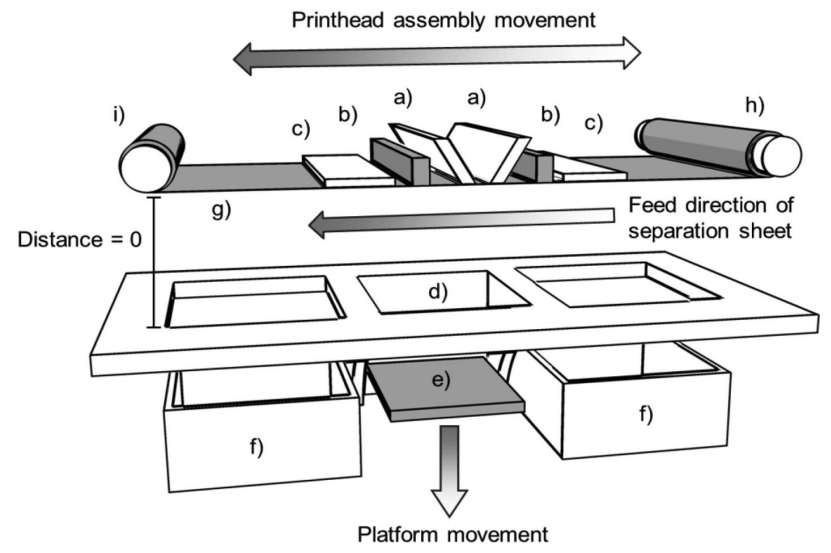

Figure 4: Schematic presentation of selective heat sintering 25 


\section{S. A. ADEKANYE et al.: ADDITIVE MANUFACTURING: THE FUTURE OF MANUFACTURING}

duced are supported by the excess material surrounding the object. ${ }^{26}$

This technology uses thermoplastic powder as its working material. The benefits of this technology are as follows: it allows inexpensive manufacturing and a good concept evaluation; the thermal print heads are less expensive and the overall cost is affordable.

\subsection{Selective laser melting}

Selective laser melting is similar to the selectivelaser-sintering process, with the main difference being between full melting and fusing in selective laser sintering. The process begins with designing a 3D CAD model; the model is broken down into parts to form a number of finite layers. For each layer, the laser scan path is calculated, defining both the boundary contour and the form of the fill sequence called the raster pattern. Layers are formed by spreading powder on the build platform and then the laser melts the powder with the scanning laser beam; the melted powder solidifies to form a $3 \mathrm{D}$ solid component. ${ }^{27} \mathrm{~A}$ schematic diagram of the process is shown in Figure 5. ${ }^{28}$

Different materials used with this technology include steel, titanium, aluminium, cobalt-chromium and nickel alloys. The benefits of using the selective-laser-melting technology are as follows:

- it minimizes material wastage and saves costs,

- improved production-development cycle,

- it allows for complex geometry to be made,

- ideal process for a low-volume production,

- improved buy-to-fly ratio,

- functionally graded parts can be produced,

- it allows for fully customized parts that suit individuals.

The disadvantages of selective laser melting are as follows:

- it is an expensive and a very slow process,

- tolerances and surface finishes are limited because of the sticking of the unused powder on the surface of the produced part.

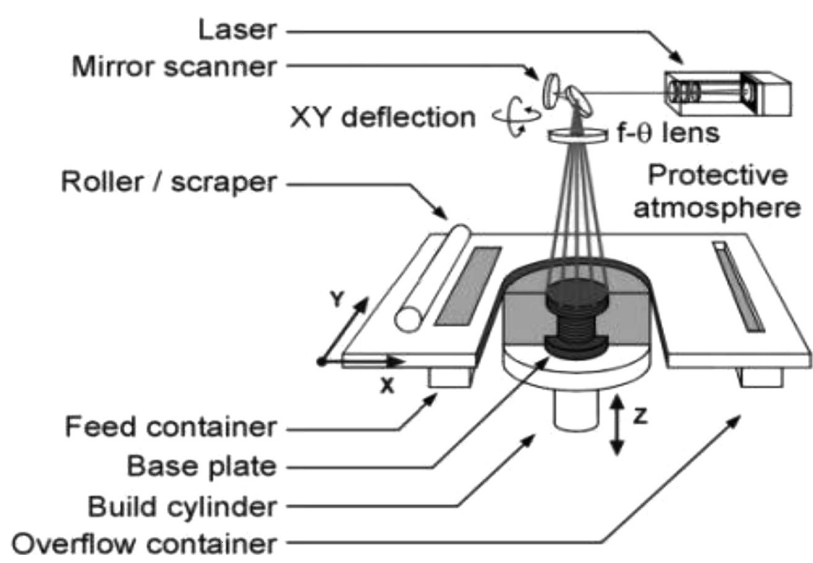

Figure 5: Schematic presentation of selective laser melting ${ }^{28}$

\section{EXTRUSION-BASED SYSTEM}

An extrusion-based system uses material extrusion where the material is heated to the molten state and then extruded through a nozzle to form parts layer by layer. The most common technology is fused deposition modeling (FDM). A schematic diagram of the process is shown in Figure 6.

Fused deposition modeling produces components by depositing extruded material in layers through a nozzle. Fused deposition modeling uses a 3D CAD program to prepare and build a model; the material is heated to the molten state and forced through the nozzle under pressure to build up a component. ${ }^{29}$ The advantages of fused deposition modeling are as follows:

- the technology supports complex geometries and cavities,

- the technology produces high-grade parts,

- it is simple to use.

The limitations of fused deposition modeling are:

- limitation on the materials that can be used,

- limited size,

- the cost of the actual machine.

This technology uses different materials for component fabrication, including acrylonitrile butadiene styrene (ABS), polylactic acid (PLA), polycarbonate (PC), polyamide (PA), polystyrene (PS), lignin, rubber, nylon and others. ${ }^{29}$

\section{SHEET-LAMINATION PROCESS}

This is an additive-manufacturing technology, which mainly uses metal sheets or paper for the manufacturing process. This technology is characterized by a low cost of production, high strength of the model, possibilities to

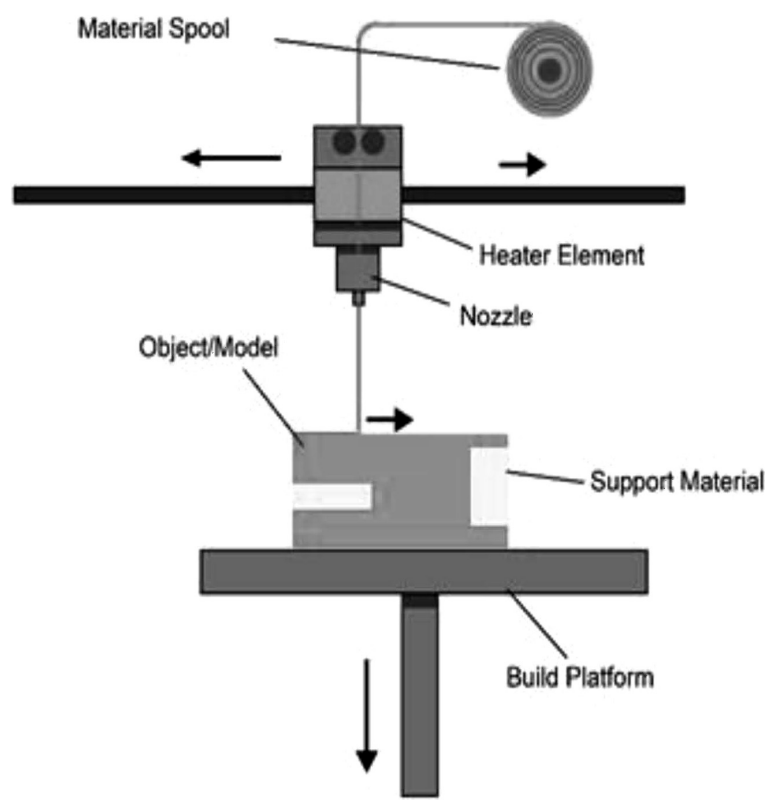

Figure 6: Presentation of an extrusion-based system ${ }^{29}$ 
control the range of speed of the process to create the outcome desired. Apart from the benefits achieved when using this technology, there are also limitations: the properties of the outcome product depends on the material used and the process of fusing the material together needs improved techniques. ${ }^{30}$

There are two variants of this process, namely: ultrasonic additive manufacturing (UAM) and laminated object manufacturing (LOM). Ultrasonic additive manufacturing (UAM) uses metal as its working material and employs the layer-by-layer techniques, whereby the layers are welded together ultrasonically. This process uses metals like aluminum, copper, stainless steel and titanium alloy. Laminated object manufacturing (LOM) incorporates the layer-by-layer lamination technique, using sheets of paper as the working material and $\mathrm{CO}_{2}$ laser for cutting a sheet that has been joined together by an adhesive to form layers of CAD-model parts. The excess material that is not part of the component being built is sliced into cubes, using a cross-hutch cutting operation. ${ }^{31}$

\section{DIRECTED ENERGY DEPOSITION}

Directed energy deposition is a type of additive manufacturing that uses the energy from a laser or electron beam to create a melt pool on the surface of the substrate, where coaxial powder or wire is deposited, following the path described by a CAD profile. An example of this process is laser metal deposition, also known as laser engineered net shaping (LENS), a process with high material-utilization efficiency and cost efficiency. ${ }^{32-41}$ The laser, or electron beam, leaves a solid track of the melted powder. A schematic diagram of this process is shown in Figure 7. The advantages of directed energy deposition include the ability to carry out a high-value repair on a part that was cost prohibitive in the past; it can also be used to manufacture parts with functionally graded materials or functionally graded

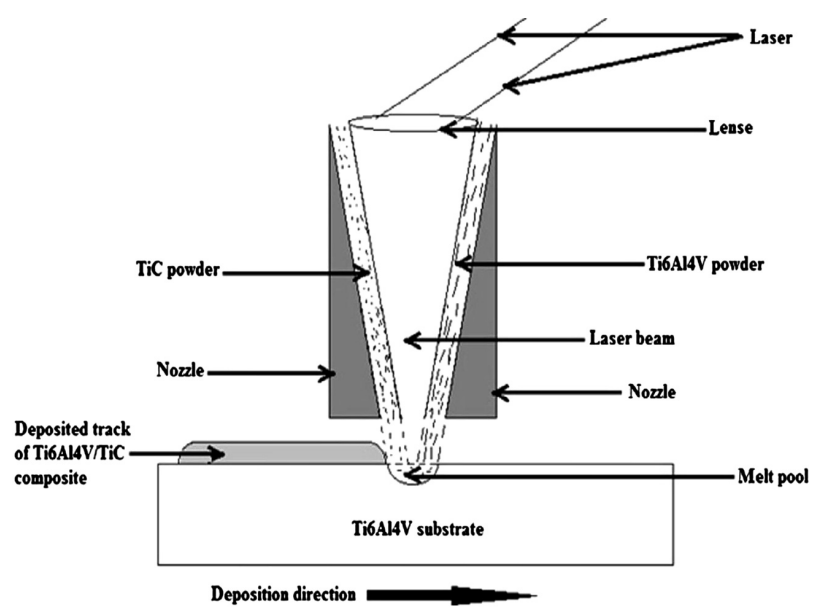

Figure 7: Schematic diagram of directed energy deposition ${ }^{41}$ coatings. ${ }^{39-41}$ The materials that can be used for this technology include metals, alloys, ceramics and composites.

Other additive-manufacturing processes are material jetting, binder jetting and the vat photopolymerization process. These types of additive manufacturing use nonmetallic based materials and their applications are limited. For further reading about these and other additive-manufacturing processes, the reader can consult references. ${ }^{42-52}$

A new 3D printing technology was developed and it will help us create metallic, free-standing 3D structures. This technology was developed by the researchers at Harvard University. ${ }^{53}$ The existing direct ink writing 3D printing technology is combined with laser annealing to ensure accurate and stable free-standing 3D structures. This technology is very useful in the applications where free-standing 3D microstructures are required, e.g., in sensors, electronics and also in biomedical applications.

\section{MATERIAL DEVELOPMENT FOR ADDITIVE MANUFACTURING}

There is constant demand for light materials with improved properties, especially in the automobile and aerospace industries, with the aim of reducing the global warming. The advent of additive manufacturing is the beginning of a new dawn in the manufacturing industries. A number of restrictions were placed on material development in the past because of thermodynamic limitations as well as the difficulties in processing some materials in the bulk form. With additive-manufacturing technologies, new materials are now being developed without any restriction. A number of complex metallic alloys are now being developed and used for the fabrication of important light-weight structures with impressive properties, using the additive-manufacturing process. ${ }^{54}$ Complex metallic alloys are intermetallic compounds with unique thermal and transport properties that cannot be found in any metal system. ${ }^{55}$

Complex metallic alloys are needed in a number of applications because of their excellent properties, but they cannot be used with the conventional manufacturing processes because of their brittleness that makes them difficult to process. These materials have low coefficients of friction, good corrosion resistance, good wearresistance properties and can now be processed using additive manufacturing. New composite materials with improved properties are introduced and used in additivemanufacturing processes, with the functional-part production now being commercialized. ${ }^{54}$ The traditional manufacturing process presents a lot of challenges when processing these materials because of the segregation of constituent materials due to the thermodynamic properties of individual materials, but additive-manufacturing technologies can be used to process these materials without such problems. 


\section{S. A. ADEKANYE et al.: ADDITIVE MANUFACTURING: THE FUTURE OF MANUFACTURING}

A number of new materials with improved properties and performances are now being developed for the additive-manufacturing technologies. These new materials include the high-temperature copper alloy, developed by NASA, with excellent properties such as retention of high strength at elevated temperatures, used in rocket engines. Other materials that present challenges with the conventional manufacturing processes and are now successfully processed using the additive-manufacturing technologies include titanium aluminide, used in the fabrication of high-speed gas-turbine blades, reactor-grade pure niobium and NiTi.

\section{CONCLUSIONS}

The concept of additive manufacturing has provided solutions to most engineering problems, especially the problems faced by product designers in the past when products needed to be designed and redesigned because of the limitations imposed by the available manufacturing process. Designers can now freely design parts without having to worry about how they will be made. This research paper presents a review on various additive-manufacturing technologies. The aim of this paper is to provide a clear description of this novel manufacturing process - the additive-manufacturing process. Each of the technologies is described in this paper, including the materials suitable for use in each technology, advantages, disadvantages. Application areas and the new material development relating to the additive-manufacturing technologies are presented. In summary, additive manufacturing is a reliable technology that can be used to manufacture prototypes, tooling and functional parts, as it is less time consuming, allowing an easy fabrication of a complex geometry, an easy production of customized and personalized parts, without any need for special tools, and low material wastage that reduces the overall cost of the production. Improvements in the computing power and the reduction in mass-storage costs paved the way for processing the large amounts of data typical of modern 3D CAD models within reasonable time frames.

A new 3D printing technology has recently been developed at Harvard University. This new additivemanufacturing technology combines the existing direct ink writing $3 \mathrm{D}$ printing technology and the annealing process. The innovation was born out of the necessity for flexible and wearable electronic devices such as sensors and in biomedical applications. The technology uses the 3D printing technology to create complex architectures, while a printed structure is simultaneously annealed in midair. This helps to increase the accuracy of the printed material, also allowing the printed material to be created in free air without the need for any support structure. This technology has opened up possibilities of creating microscopic metallic free-standing 3D structures without an auxiliary support and in a single manufacturing run.

\section{REFERENCES}

${ }^{1}$ J. Scott, N. Gupta, C. Wember, S. Newsom, T. Wohlers, T. Caffrey, Additive manufacturing: status and opportunities, Science and Technology Policy Institute, 2012, https://www.ida.org/stpi/occasionalpapers/papers/AM3D_33012_Final.pdf

2 J. P. Kruth, M. C. Leu, T. Nakagawa, Progress in additive manufacturing and rapid prototyping, CIRP Annals, 47 (1998), 2, doi:10.1016/S0007-8506(07)63240-5

${ }^{3}$ T. Wohlers, T. Caffrey, Additive manufacturing: going mainstream, manufacturing engineering, http://advancedmanufacturing.org/ additive-manufacturing-going-mainstream/, 2013

${ }^{4}$ F. Liou, K. Slattery, M. Kinsella, J. Newkirk, H. N. Chou, R. Landers, Applications of a hybrid manufacturing process for fabrication of metallic structures, Rapid Prototyping Journal, 13 (2007), 4, doi:10.1108/13552540710776188

${ }^{5}$ R. M. Mahamood, E. T. Akinlabi, M. Shukla, S. Pityana, Revolutionary additive manufacturing: an overview, Lasers in Engineering, 27 (2014), 3-4, 161-178

${ }^{6}$ N. Hopkinson, P. Dickens, Rapid prototyping for direct manufacture, Rapid Prototyping Journal, 7 (2001), 4, doi:10.1108/EUM0000000005753

${ }^{7}$ Y. L. Hou, T. T. Zhao, C. H. Li, Y. C. Ding, The manufacture of rapid tooling by stereo lithography, Advanced Materials Research, 102-104 (2010), 578-582

${ }^{8}$ L. Hao, S. Dadbakhsh, Materials and process aspects of selective laser melting of metals and metal matrix composites: a review, Chinese Journal of Lasers, 36 (2009), 12, doi:10.3788/CJL20093612.3192

${ }^{9}$ V. Petrovic, J. V. H. Gonzalez, O. J. Ferranda, J. D. Gordillo, J. R. B. Puchades, L. P. Grinan, Additive layered manufacturing: sectors of industrial application shown through case studies, International Journal of Production Research, 49 (2011), 4, doi:10.1080/00207540903479786

${ }^{10}$ S. F. S. Shirazi, S. Ghanehkhani, M. Mehrali, H. Yarmand, H. S. C. Metselaar, N. A. Kadri, N. A. A. Usman, A review on powder-based additive manufacturing for tissue engineering: selective laser sintering and inkjet 3D printing, Science and Technology of Advance Materials, 16 (2015), 3, doi:10.1088/1468-6996/16/3/033502

${ }^{11}$ M. Dickson, Soft strain sensors fabricated through additive manufacturing, MRS Bulletin, 40 (2015), 6, doi:10.1557/mrs.2015.124

${ }^{12}$ A. R. R. Bineli, A. P. G. Peres, L. F. Bernardes, A. L. Jardini, R. Filho, Design of microreactor by integration of reverse engineering and direct metal laser sintering process, Proceedings of the 5th international workshop on hydrogen and fuel cells, Campinas, 2010

${ }^{13}$ O. Nyrhila, Characterization of Process Parameter for Direct Metal Laser Sintering, Ph.D. Thesis, Nagoya Institute of Technology, 2005

${ }^{14}$ A. Bineli, A. Peres, A. Jardini, R. Filho, Direct metal laser sintering: technology for design and construction of microreactors, Proceedings of the 6th Brazilian Conference on Manufacturing Engineering, 2011

${ }^{15}$ R. Aulus, R. Maciel, Direct metal laser sintering (DMLS): technology for design and construction of microreactors, Science and Technology of Advance Materials, 7 (2015), 2

${ }^{16}$ L. Morgan, L. Ulf, H. Ola, Rapid manufacturing with electron beam melting (EBM) - a manufacturing revolution, 2006, 433-438, https://sffsymposium.engr.utexas.edu/Manuscripts/2003/2003-41-Lar sson.pdf

${ }^{17}$ L. Ladani, L. Roy, Mechanical behavior of TI-6AL-4V manufactured by electron beam additive fabrication, Proceedings of the ASME International Manufacturing Science and Engineering Conference, Madison, 2013

${ }^{18}$ S. Biamino, A. Penna, U. Ackelid, S. Sabbadini, O. Tassa, P. Fino, M. Pavese, P. Gennaro, C. Badini, Electron beam melting of Ti-48Al-2Cr-2Nb alloy: microstructure and mechanical properties investigation, Intermetallics, 19 (2010), 6, doi:10.1016/j.intermet. 2010.11.017 


\section{S. A. ADEKANYE et al.: ADDITIVE MANUFACTURING: THE FUTURE OF MANUFACTURING}

${ }^{19}$ A. Neira, Thermal Modeling and Simulation of Electron Beam Melting for Rapid Prototyping on Ti6Al4V Alloys, Ph.D. Dissertation, North Carolina State University, Raleigh, NC, 2012

${ }^{20}$ D. Bouk, H. Kaal, Selective Laser Sintering of Metals, Proceedings of ASME, American Society of Mechanical Engineers, New York, 2015

${ }^{21}$ H. J. Niu, I. T. H. Chang, Selective laser sintering of gas atomized M2 high speed steel powder, Journal of Materials Science, 35 (2000), 1, doi:10.1023/A:1004720011671

${ }^{22}$ M. Peterson, A. Kalz, Characterization and comparison of materials of selective laser sintering, Journal of Materials Processing Technology, 21 (2013) 3, 21-22

${ }^{23}$ C. Telenko, C. C. Seepersad, Assessing energy requirements and material flows of selective laser sintering of nylon parts, Proceedings of the Solid Freeform Fabrication Symposium, Austin, USA, 2010 289-297

${ }^{24} \mathrm{~S}$. Caroly, Design rules for selective laser sintering, https://www.me.utexas.edu/ ppmdlab/files/designers.guide.sls.pdf

${ }^{25}$ M. Baumers, C. Tuck, R. Hague, Selective heat sintering versus laser sintering: comparison of deposition rate, process energy consumption and cost performance, https://sffsymposium.engr.utexas.edu/ sites/default/files/2015/2015-9-Baumers.pdf

${ }^{26}$ R. M. Mahamood, E. T. Akinlabi, M. Shukla, S. Pityana, Material efficiency of laser metal deposited TI6AL4V: effect of laser power, Engineering Letters, 21 (2013), 1, http://www.engineeringletters. com/issues_v21/issue_1/EL_21_1_03.pdf

${ }^{27}$ A. Diatlov, D. Buchbinder, W. Meiners. K. Wissenbach, Towards surface topography: Quantification of Selective Laser Melting (SLM) built parts, Review of selected measurement methods and ongoing report on development of measurement specifications, 2011

${ }^{28}$ Additive Manufacturing Processes, www.slidehot.com/9673714743

${ }^{29}$ A. K. Sood, R. K. Ohdar, S. S. Mahapatra, Parametric appraisal of mechanical property of fused deposition modeling processed parts, Materials and Design, 31 (2010), 201-246

${ }^{30}$ L. Gibson, D. W. Rosen, B. Stucker, Sheet lamination processes: additive manufacturing technologies, Journal of Materials and Manufacturing, 23 (2012) 3, 223-252

${ }^{31}$ C. M. Cheah, Rapid sheet metal manufacturing, International Journal of Advanced Manufacturing Technology, 19 (2002), 510-515

${ }^{32}$ R. M. Mahamood, E. T. Akinlabi, Effect of processing parameters on wear resistance property of laser material deposited titanium-alloy composite, Journal of Optoelectronics and Advanced Materials, 17 (2015) 9-10, 1348-1360

${ }^{33}$ R. M. Mahamood, E. T. Akinlabi, Process parameters optimization for material deposition efficiency in laser metal deposited titanium alloy, Lasers in Manufacturing and Materials Processing, 3 (2016), 1, doi:10.1007/s40516-015-0020-5

${ }^{34}$ R. M. Mahamood, E. T. Akinlabi, Effect of laser power and powder flow rate on the wear resistance behaviour of laser metal deposited TiC/Ti6Al4V composites, Materials Today: Proceedings, 2 (2015) 4-5, 2679-2686

${ }^{35}$ R. M. Mahamood, E. T. Akinlabi, M. Shukla, S. Pityana, Characterization of Laser Deposited Ti6A4V/TiC Composite, Lasers in Engineering, 29 (2014) 3-4, 197-213

${ }^{36}$ R. M. Mahamood, E. T. Akinlabi, S. A. Akinlabi, Laser power and scanning speed influence on the mechanical property of laser metal deposited titanium-alloy, Lasers in Manufacturing and Materials Processing, 2 (2014) 1, 43-55
${ }^{37}$ R. M. Mahamood, E. T. Akinlabi, M. Shukla, S. Pityana, Scanning Velocity Influence on Microstructure, Microhardness and Wear Resistance Performance on Laser Deposited Ti6A14V/TiC Composite, Materials and Design, 50 (2013), 656-666

${ }^{38}$ R. M. Mahamood, E. T. Akinlabi, M. Shukla, S. Pityana, Characterizing the Effect of Laser Power Density on Microstructure, Microhardness and Surface Finish of Laser Deposited Titanium Alloy, Journal of Manufacturing Science and Engineering, 135 (2013), 6, doi:10.1115/1.4025737

${ }^{39}$ J. Scott, N. Gupta, C. Weber, S. Newsome, T. Wohlers, T. Caffrey, Additive Manufacturing: Status and Opportunities, https://cgsr. llnl.gov/content/assets/docs/IDA_AdditiveM3D_33012_Final.pdf

${ }^{40}$ R. M. Mahamood, E. T. Akinlabi, Laser metal deposition of functionally graded Ti6Al4V/TiC, Materials \& Design, 84 (2015), 402-410

${ }^{41}$ R. M. Mahamood, E. T. Akinlabi, M. Shukla, S. Pityana, Functionally graded material: An overview, Proceedings of the World Congress on Engineering, London, UK, 2012, 1593-1597

${ }^{42}$ A. D. Halvorsen, P. Vaidya, M. Robinson, D. L. Schulz, Transforming a laser micromachine into a direct-write tool for electronic materials, Journal of Micro-Electronics and Electronic Packaging, 5 (2008), 116-121

${ }^{43}$ K. K. B. Hon, L. Li, I. M. Hutchings, Direct writing technology advances and developments, CIRP Annals, 57 (2008) 2, 601-620

${ }^{44}$ A. Lutfurakhmanov, G. K. Loken, D. L. Schulz, I. S. Akhatov, Capillary-based liquid microdroplet deposition, Applied Physics Letters, 97 (2010) 12, 1-3

${ }^{45}$ D. B. Chrisey, A. Pique, R. Modi, H. D. Wu, R. C. Y. Auyeung, H. D. Young, Direct writing of conformal microscopic electronic device by MAPLE DW, Applied Surface Science, 168 (2000) 1-4, 345-352

${ }^{46}$ M. Burns, Automated Fabrication: Improving Productivity in Manufacturing, Prentice Hall, Eaglewood Cliffs, NJ, 1993

${ }^{47}$ Wohlers Report, Additive manufacturing and 3D printing state of the industry, https://wohlersassociates.com/state-of-the-industry-reports.html

${ }^{48}$ J. P. Kruth, M. C. Leu, T. Nakagawa, Progress in additive manufacturing and rapid prototyping, CIRP Annals - Manufacturing Technology, 47 (1998) 2, 525-540

${ }^{49}$ J. Kietzman, L. Pitt, P. Berthon, Disruptions, decisions, and destinations: Enter the age of 3 -D printing and additive manufacturing, Business Horizons, 58 (2015) 2, 201-210

${ }^{50}$ K. Chan, Metal Additive Manufacturing: A Review, Journal of Materials Engineering and Performance, 31 (2016) 6, 1917-1928

${ }^{51}$ R. M. Mahamood, E. T. Akinlabi, Influence of scanning speed intermetallic produced in-situ in laser metal deposited TiC/Ti6Al4V composite, Mater. Tehnol., 51 (2017) 3, 473-478, doi:10.17222/ mit.2016.096

${ }^{52}$ Y. Zhai, D. A. Lados, J. L. Lagoy, Additive Manufacturing: Making Imagination the Major Limitation, JOM, 66 (2014) 5, 808-816

${ }^{53}$ M. A. Skylar-Scott, S. Gunasekaran, J. A. Lewis, Laser-assisted direct ink writing of planar and 3D metal architectures, PNAS, 113 (2016) 22, doi:10.1073/pnas.1525131113

${ }^{54}$ S. Kenzari, D. Bonina, J. M. Dubois, V. Fournée, Complex metallic alloys as new materials for additive manufacturing, Science and Technology of Advanced Materials, 15 (2014) 2, 1-9

${ }^{55}$ J-M. Dubois, Properties and applications of quasicrystals and complex metallic alloys, Chem. Soc. Rev., 41 (2012), 6760-6777 